Agro-Science Journal of Tropical Agriculture, Food, Environment and Extension Volume 9 Number 3 September 2010 pp. 209 -214

ISSN 1119-7455

\title{
INFLUENCE OF FARMERS' SOCIO-ECONOMIC AND TECHNOLOGICAL CHARACTERISTICS ON SOYBEAN SEEDS TECHNOLOGY ADOPTION IN SOUTHERN BORNO STATE, NIGERIA.
}

\author{
Idrisa $^{1}$, Y.L. Ogunbameru ${ }^{2}$, N.B.O. and Amaza ${ }^{3}$, P.S \\ Department of Agricultural Economics and Extension Services, University of Maiduguri, Nigeria.
}

\begin{abstract}
Soybean is one of the most important sources of protein known to man. It is the cheapest source of protein in terms of accessibility, especially in the developing countries. The importance of the crop informed its introduction to Borno State in 2004. this study examined the determinants of likelihood of improved soybean seeds adoption among farmers in southern Borno State. Data for the study were obtained from 360 respondents selected through multi-stage sampling procedure. Purposive and random sampling techniques were employed at the various stages of selection. Inferential statistical technique- the Logit model-was used to estimate the likelihood of technology adoption among the respondents. The results of the study revealed that farm size and expenditure on hired labor were the most important socio-economic factors that significantly $(p \leq 0.05)$ influenced the likelihood of adoption of improced soybean seeds among the respondents while yield of soybean $(p \leq 0.01)$, household utilization of soybean $(p \leq 0.05)$ and maturity period of soybean $(p \leq 0.05)$ were the significant technology characteristics that influenced the likelihood of adoption of improved soybean seeds by farmers in the area. Based on the findings of this study, it was recommended that: labor-saving technologies be made available to farmers in order to cushion the effect of their expenditure on hired labor, farmers should also be linked to sources of financial support so as to enable them afford hired labor,
\end{abstract}

Key Words: Socio-economic characteristic, Technology characteristics, Soybean seeds, Adoption, Borno State

\section{INTRODUCTION}

Soybean is the richest sources of plant protein known to man (Odusanya, 2002). It is also the cheapest and most readily available source of protein, especially in developing countries. It is therefore very important in rectifying the protein deficiency which is very common in diets of people, particularly those in the rural areas. Onyibe, J.E., Kamara, A.Y and Omoigui, L.O. (2006) noted that soybean has the capacity to improve soil fertility by fixing nitrogen into the soil through nitrification which is carried out by nitrogenfixing bacteria resident in the roots nodule of soybeans. Soybean also has the capacity to improve the nutritional status of households, improve incomes, enhance productivity of other crops (FAO, 1998; Fakiyesi, 2001; Shala and Stacey, 2001).

As recognized by Doss (2003; 2006), one way of improving agricultural productivity, in particular and rural livelihood in general, is through the introduction of improved agricultural technologies to farmers. Doss, C.R., Mwangi, W., Verkuiji, H. and de Groote, H. (2003) also opined that adoption of improved technologies is an important mean to increase the productivity of small holder agriculture in Africa, thereby fostering economic growth and improved wellbeing for millions of the poor households. Low adoption of improved agricultural production technologies that can increase farmers' productivity is generally known to lead to reduced agricultural output. Earlier studies ( Seyoum, E.T., Battese, G.E. and Fleming, E.M., 2006; Obwoma, M., 2000; Ajibefun, 2006) opined that the low rate of adoption of improved agricultural technologies could be due to low expected benefits from the practice or could be due to other factors such as farmers' characteristics or technology factors which may not encourage the adoption of technologies by farmers. Use of local crop varieties is also recognized as major impediments to the growth of African agriculture (Yates and Kiss, 1992; Valnauwe and Giller, 2006). This is evidenced by low and declining yield per hectare of major crops in Nigeria as revealed by NBS (2006). It is in recognition of this situation that, Ouma, J.O., De Groot, H. and Owuor, G. (2006) suggested that the use of improved technologies will continue to be a critical input for improved farm productivity.

Soybean was introduced to Borno State as a commercial crop in the year 2004 to contribute to food 
security, improve nutritional status, reduce poverty among farmer and reduce environmental degradation (PROSAB 2003). To achieve this, it is necessary that farmers adopt the improved soybean seed as a production technology. The study was therefore designed to find out the likelihood of adoption of improved soybean seeds by farmers in the project area following its introduction in the year 2004. The study also aimed at ascertaining the socio-economic and technology specific factors that influenced the decision of farmers to adopt the improved soybean seed as a production technology.

\section{METHODOLOGY}

The study was conducted in southern Borno State, Nigeria. Multi-stage sampling technique was used in selecting communities and respondents for the study. In the first stage, all the three Local Government Areas (LGAs) where soybean production was promoted by a project - Promoting Sustainable Agriculture in Borno State (PROSAB) were purposely selected out of the 27 LGAs in the State. These LGAs include Biu, Hawul and Kwaya-kusar. The second stage involved selecting four soybean producing communities from each of Biu and Hawul LGAs, while one soybean producing community was selected from Kwaya-kusar LGA, giving a total of nine communities used for the study. This was done in proportion to the soybean producing communities in the LGAs. In stage three, 360 respondents were selected proportionately from the soybean producing communities earlier selected. The numbers of respondents selected from each LGA are: Biu, 158 (43.89\%), with two communities providing 39 respondents each and two communities providing 40 respondents each; Hawul, 176 (48.89\%), with each of the four communities providing 44 respondents each ; Kwaya Kusar, 26 $(07.22 \%)$, all from one community. Selection of respondents at community level was randomly done from the list of soybean farmer earlier provided by PROSAB. These 360 respondents were administered the interview schedules. Inferential statistic - the Logit model - was used to analyze the data collected for the study.

\section{Data analysis}

Data for the study were obtained mainly from primary sources. These were collected through the use of interview schedules administered to the 360 selected respondents. The Logit regression model was used to establish relationship between the likelihood of adoption of improved soybean seed and the various factors affecting it. The application of the Logit model in explaining relationships between dependent variable and a set of explanatory variables is well demonstrated. The Logit model has been shown to be more precise and appropriate in analyzing the relationships involving binary dependent variable and a set of independent variables. (Capps and Crammer, 1985; Akinola, 1987; Adesina and Seidi, 1995)

Theoretically, the Logit model is expressed as:

$\mu=B_{0+} B_{1} X_{1}+B_{2} X_{2}+\ldots \ldots \ldots B_{n} X_{n}$

Where:

$\mu=$ Likelihood of Adoption, otherwise labeled as ADOPT. It is quantified as:

Adopter = any farmer that devoted at least $10 \%$ of his/her land for soybean production; and Nonadopters $=$ any farmer that devotes less than $10 \%$ of his/her land for soybean production, as used by Ojiako, I.A., Monyong, V.M. and Ikpi, A.E. (2007).

$\mathrm{B}_{0}=$ intercept;

$B_{1 \ldots \ldots . . .}=$ estimated parameters;

$X_{1 \ldots \ldots . . . n}=$ Set of independent variables.

For the Logit Model, the equation for the relationship between socio-economic characteristics of respondents and the likelihood of their adoption is specified as:

ADOPT

$=B_{0}+B_{1} A G E+B_{2} S E X+B_{3} M S T+B_{4} E D U+B_{5} H H S+B_{6} F M$

$S+B_{7} F X P+B_{8} X P L+e$

Where:

ADOPT $=$ likelihood of adoption, Dummy variable (1 for adoption and 0 for non adoption).

$\mathrm{AGE}=$ Age of respondents (measured in years) .

SEX $=$ Gender of respondents (male or female).

MST $=$ Marital status

EDU $=$ Educational level (measured in years spent in formal schooling).

HHS = Household size (measured in persons living under the care of the respondent).

FMS = Farm size (total area of land owned/operated by respondent measured in hectares).

EXP $=$ Farming experience (measured in number of years spent as soybean farmer

$\mathrm{XPL}=$ Expenditure on hired labour measured in Naira value

$\mathrm{e}=$ Error term which satisfies all the econometric conditions of Ordinary Least Square (OLS).

The equation for the relationship between technology characteristics and the likelihood of adoption is specified as:

$\mathrm{ADOPT}=B o+B_{1} Y L D+B_{2} M T T+B_{3} U T L+\mathrm{e}$

Where:

UTL = Utilization of soybean at household level, Dummy variable.

YLD = Yield (physical output of improved variety measured in kilogram).

MTT = Maturity period (measured in days improved crop spend on field before harvesting)

$\mathrm{e}=$ Error term which satisfies all the econometric conditions of Ordinary Least Square (OLS). 


\section{RESULTS AND DISCUSSION}

\section{Socio-economic Factors Affecting the Likelihood of Technology Adoption}

The socio-economic characteristics that significantly influenced the adoption of improved soybean seeds by farmers include farm size and expenditure on hired labor. These factors were statistically significant at $5 \%$.

The coefficient of farm size was found to be significant $(p \leq 0.05)$ but negatively related with the adoption of improved soybean seed in the study area (Table 1). This confirms the hypothesis that small farmers, in comparism to large farmers, adopt improved technologies at a faster rate if additional gains are substantial (Shiyani, R.I., Joshi, P.K., Asokam, M. and Bantilan, M.C.S., 2002). This might likely be due to two reasons. First, small farmers live at subsistence level that attracts them to adopt improved varieties which give better yields, earn more income and thereby helping in raising their standard of living. Secondly, limited availability of improved seeds might have compelled large farmers to partly continue producing alternative crops or recycled local seeds. As a result, they lagged behind in adopting improved seed. This also agrees with the findings of Allaudin and Tisdell, (1988) that small farmers adjust quickly and adopt new innovations at a faster rate than large-scale farmers.

Table 1 further shows a positive and significant relationship $(\rho \leq 0.05)$ between farmers' expenditure on hired labor and adoption of improved soybean seeds in the study area. This means that soybean farmers who had resources to engage the services of hired labor were more likely to adopt improved soybean as a production technology compared with farmers who depended solely on the family labor. This could be explained by the fact that hired labor is generally used by medium-scale and large-scale farmers in Nigerian agriculture where labor-saving technologies are not always readily available. This coupled with the fact that the family labor, even though it constitutes a bulk of the labor force used in agriculture in Nigeria, is not always available for farm operations (Bamire and Manyong,
2003). Consequently, soybean farmers who could afford to hire labor will tend to maximize returns on investment in soybean farming. This can trigger adoption of improved soybean seed among other production technologies. It is generally believed that in the rural communities, labor is available and relatively affordable. As such, apart from providing employment for the abundant 'idle' human resource and promoting large-scale production, patronizing hired labor in farming communities could also encourage the diversion of rural labor force into generating non-farm incomes and thereby diversifying sources of income for rural dwellers.

\section{Technology-specific Factors Affecting the Likelihood of Technology Adoption Among the technology-specific} characteristics considered for the study, the results showed that yield of soybean was found to be the most significant factor $(\rho \leq 0.01)$ in influencing the likelihood of adoption of soybean seed technology while respondents' utilization of soybean at household level and maturity period of soybean were found to be significant $(\rho \leq 0.05)$ in influencing the decision to adopt improved soybean as production technology (Table 2). Even though soybean was introduced recently into the study area, it has rapidly gained popularity in terms of household usage. Results from the study showed that virtually all farmers in the study area use soybean at household level. Soybean is rich in protein (Sanginga, P.C., Adesina, A.A., Manyong, V.M. and Dashiel, K.E., 1999), which is commonly deficient in the diet of most communities, especially rural communities. This probably informed why soybean had wide range of uses in the study area. Some of the uses of soybean among households in the study area include preparation of soypulp, soy akara, soy cheese/soy milk, soy dadawa, and weaning food. This implies that soybean has come to the aid of many households as cheap source of protein. Given that majority of the population is engaged in farming, it is obvious that they will plant soybean on their farms even if only to meet their household needs. This agrees with earlier findings by Sanginga et al., (1999) that household utilization formed a major reason for the adoption of soybean in Benue State. 
Table 1: Logit Estimate of Likelihood of Adoption Based on Respondents' Socio-economic characteristics

\begin{tabular}{|c|c|c|c|c|c|c|}
\hline Likelihood of Adoption & Coeficient & Std. Error & $\mathrm{Z}$ & $\mathrm{P}>|\mathrm{z}|$ & \multicolumn{2}{|c|}{ (95\% Conf. Interval) } \\
\hline Education & .0299189 & .0700357 & 0.49 & 0.669 & .1073486 & .1671863 \\
\hline Farm size & -.6723619 & .2962722 & -2.27 & $0.023^{* * *}$ & -1.253045 & -.0916791 \\
\hline Farming experience & .2033259 & .1127525 & 1.80 & 0.071 & .0176649 & .4243168 \\
\hline Use of hired labor & .2903237 & .291032 & 1.00 & 0.318 & .860736 & .2800886 \\
\hline Length of membership & .0302463 & .0712281 & 0.42 & 0.671 & .1698508 & .1093581 \\
\hline Cons & .189562 & .73451 & 0.26 & 0.796 & 1.250051 & 1.629175 \\
\hline
\end{tabular}

Table 2: Logit estimate of likelihood of adoption based on technology-specific characteristics

\begin{tabular}{|c|c|c|c|c|c|c|}
\hline Likelihood of Adoption & Coefficient & Std. Err. & $\mathrm{Z}$ & $\mathrm{P}>|\mathrm{z}|$ & \multicolumn{2}{|c|}{ (95\% Conf. Interval) } \\
\hline Use of Soybean & 1.115597 & .494053 & 2.47 & $0.014^{* * *}$ & 1.022848 & 1.216756 \\
\hline Maturity Period & -1.369532 & .3474143 & -1.24 & $0.015^{* *}$ & -.8329999 & 2.251644 \\
\hline Yield of Soybean & 1.000661 & .00016 & 4.13 & $0.000^{* * * *}$ & 10000347 & 1.000974 \\
\hline
\end{tabular}

$* *=$ Significant at $5 \%$

$* * *=$ Significant at $1 \%$

Maturity period was also found to be an important determinant influencing the adoption of improved soybean seed in the study area. The variable was significant at $5 \%$ probability level with negative sign (Table 2). This means that adoption of improved soybean seed by respondents increased with decrease in time taken to maturity by the crop. This is expected as early maturity gives the crop an advantage, especially in the study area which is prone to drought. One of the characteristics of the ecology of the study area is the dry Harmattan wind which sets in at the end of the rainy season, thereby facilitating pod shattering (Sanginga et al., 1999). Early maturity therefore enables soybean crop to escape pod shattering, pest infestation and terminal drought due to receding soil moisture. These factors give it advantage over alternative crops such as the traditional cowpea which is highly vulnerable to all the above due to its relatively long maturity period. As such, the probability of adoption of soybean increased with decrease in its maturity period.

Yield of soybean was found to be a very important factor that influenced the adoption of improved soybean seed among farmers in the study area. The yield variable was found to be positive and significant at $1 \%$ level of probability (Table 2). Yield is a direct measure of seed's performance and a crop variety that is high yielding stands to be adopted by farmers since high yield would raise output and subsequent gross earning. This finding agrees with Ojiako, et al.,
(2007) that yield of soybean was significant in influencing the adoption of improved soybean in northern Nigeria. Adesina and Zinna (1993) also reported that yield significantly influenced farmers' decision to adopt improved mangrove swamp varieties of rice in Sierra Leone.

Alimi (1991) observed that one of the main problems facing agricultural production in developing countries is low yield. The practice of planting traditional/low yielding variety of crops by farmers may partly be responsible. This necessitated the development of high yielding varieties of crops by agricultural research institutes with the hope that these improved varieties of crops will be adopted by farmers so as to improve their yield. To that effect, a variety of crop that has high capacity for high yielding has high chances of being adopted. The likelihood of adoption is even higher if the crop variety does not depend so much on complementary inputs such as fertilizers and pesticides. Soybean being a leguminous crop has the capacity to fix atmospheric nitrogen into the soil. This implies that it can generate part of its nutrient requirements, thus, it can guarantee yield even without supply of fertilizers (Onyibe et al., 2006). Soybean is also not susceptible to most of the local pests and diseases which hinder the production of related crops such as cowpea. All these give soybean some added advantage over other grain legumes. 
Idrisa, Y.L. Ogunbameru, N.B.O. and Amaza, P.S.

\section{CONCLUSIONAND RECOMMENDATIONS}

In this study, the factors affecting the likelihood of adoption of improved soybean seed by farmers in southern Borno State were analyzed. The study found that expenditure on hired labor significantly $(\rho \leq 0.05)$ influenced the likelihood of adoption of improved soybean seed among farmers in the study area. Utilization of soybean at household level also influenced the likelihood of adoption of improved soybean seed by the respondents $(\rho \leq 0.05)$. Yield of soybean was the most important factor that significantly $(\rho \leq 0.01)$ influenced the likelihood of adoption. It was therefore concluded that yield of soybean influenced adoption among farmer more than any other technology characteristic. The study also concluded that resource endowed farmers who could afford hired labor adopted the improved soybean seed more than their resource constrained counterparts. Further more, it was concluded that utilization of soybean at household level significantly influenced the likelihood of adoption of improved soybean seed among farmers in the study area.

Based on the findings of this study, it was recommended that labor-saving technologies be made available to farmers to cushion the effect of expenditure on hired labor; Farmers should also be linked to sources of financial support so as to enable them afford hired labor; Improved seeds that possess high yielding and early maturing characteristics should be provided to farmers; while extension service should educate and encourage farmers on the utilization of soybean as a household food item.

\section{REFERNCES}

Adesina, A.A. and Seidi, S. (1995). Farmers' perception and adoption of new agricultural technologies: Analysis of modern mangrove rice varieties in Guinea Bissau. Quarterly Journal of International Agriculture, 34: 358-385.

Adesina, A.A. and Zinna. M.M. (1993). Technology characteristics, farmers' perception and adoption decision: A Tobit model application in Sierra Leone.Agricultural Economics, 19: 297311.

Ajibefun, I.A. (2006). Linking socio-economic and policy variables to technical efficiency of traditional Agricultural production: Empirical evidence from Nigeria. Paper presented at International Association of Agricultural Economists' Conference, Gold Coast, Australia, August 12-26.

Akinola, A.A. (1987). An application of Tobit analysis to the adoption of Tractor Hiring Services Scheme in Nigeria. Oxford Agricultural Studies, 16: 70-82.

Allaudin, M. and Tisdell, C.A. (1988). Dynamics of adoption and diffusion of High Yielding Varieties (HYV) technology: New evidence of inter-farm differences in Bangladesh.OccasionalPaper No. 155. Department of Economics, The University of New Castle, Australia.

Alimi, T. (1991). Influence of socio-economic characteristics of smallholder farmers on resource availability in farming. Rural Development in Nigeria, 4 (1): 1-7.

Bamire, A.S. and Manyong, B. (2003). Profitability of intensification technologies among small- holder maize farmers in the forest-savannah transition zone of Nigeria. Agriculture, Ecosystem and Environment, 100(1\&2): 111-118.

Capps, O. and Krammer, R. (1985). Analysis of food stamp participation using qualitative choice model. American Journal of Agricultural Economics, 67: 49-59.

Doss, C. R. (2003). Analyzing technology adoption using micro studies: Limitations, challenges and opportunities for improvement. Agricultural Economics 34: 207-219.

Doss, C. R. (2006). Understanding farm level technology adoption: Lessons learnt from CIMMYT's micro-survey in Eastern Africa. CYMMIT Economic Working Paper No. $30-07$, Mexico, D.F.

Doss, C. R., Mwangi, W., Verkuiji, H. and de Groote, H. (2003). Adoption of maize and wheat technologies in Eastern Africa: A synthesis of finding of 22 case studies. CYMMIT Economic Working Paper No. 30 - 06, Mexico, D.F.

F.A.O. (1998):Food and Agriculture Organization of the United Nations. Energy for Sustainable Development and Food Security in Africa. Food and Agriculture Organization of the United Nations, Rome, Italy.

Fakiyesi, O. M. (2001). "Encouraging Growth to reduce Poverty in Nigeria". In: C.B.N.: Economic and Financial Review Vol. 39, No. 2, 132-137. 
PROSAB (2003). Promoting Sustainable Agriculture in Borno State. Project Implementation Plan, October 2003 to October 2008.

Obwona, M. (2000). Determinants of technical efficiency differentials among small and medium scale farmers in Uganda: A case of tobacco growers. Final Research Report presented at a Biennial Workshop, Nairobi, Kenya.

Ojiako, I.A., Manyong, V.M. and Ikpi, A.E. (2007). Determinants of rural farmers' improved Soybean adoption decision in northern Nigeria. Journal of Food, Agriculture and Environment, 5 (2): 215223.

Odusanya, R. (2002). Powerful benefits of soybeans: Food, beverages and seasonings. Saturday punch (column 1) Nigeria, January 12, P.33.

Ouma, J.O., De Groot, H. and Owuor, G. (2006). Determinants of improved maize seed and fertilizer use in Kenya: Policy implication. Paper presented at the International Association of Agricultural Economists' Conference, Gold Cost, Australia, August 12-18.

Onyibe, J.E., Kamara, A.Y. and Omoigui, L.O. (2006). Guide to Soybean Production in Borno State. International Institute of Tropical Agriculture, Ibadan.
Sanginga, P.C., Adesina, A.A., Manyong, V.M. and Dashiell, K.E. (1999). Social impact of Soybean in Nigeria's Southern Guinea Savanna. International Institute for Tropical Agriculture, Ibadan.

Seyoum, E.T., Battese, G.E. and Fleming, E.M. (1998). Technical efficiency and productivity of maize farmers in Eastern Ethiopia: A case study of farmers within and outside the asakawa-Global 2000 Project. Agricultural Economics 19: 341348.

Shala and Stacey, (2001). United States Department of Agriculture: Economic Research Service. Food Security Assessment, Regional Overview Information Bulletin.

Shiyani, R.L., Joshi,P.K., Asokam,M. and Bantilan, M.C.S. (2002). Adoption of improved Chickpea Varieties: Krishak Bharati Cooperative (KRIBHCO) Experience in tribal region of Gujurat, India. Agricultural Economics, 27: $33-$ 39. 